\title{
Effects of weight loss on the cardiac parameters of obese dogs ${ }^{1}$
}

\author{
Gláucia B.P. Neto², Márcio A. Brunetto², Marlos G. Sousa², Aulus C. Carciofi ${ }^{3}$ \\ and Aparecido A. Camacho ${ }^{3}$
}

\begin{abstract}
Pereira-Neto G.B., Brunetto M.A., Sousa M.G., Carciofi A.C. \& Camacho A.A. 2010. Effects of weight loss on the cardiac parameters of obese dogs. Pesquisa Veterinária Brasileira 30(2):167-171. Setor de Clínica Médica Veterinária, Faculdade de Ciências Agrárias e Veterinárias, Universidade Estadual Paulista, Jaboticabal, SP 14884900, Brazil. E-mail: glaucia.vet@gmail.com

Obesity is one of the most frequent nutritional problems in companion animals and can lead to severe health problems in dogs and cats, such as cardiovascular diseases. This research aimed to evaluate the structural and functional cardiac changes after weight loss in obese dogs. Eighteen obese healthy dogs were assigned into three different groups, according with their initial body weight: Group I (dogs up to $15 \mathrm{~kg}$ ), Group II (dogs weighing between 15.1 and $30 \mathrm{~kg}$ ), and Group III (dogs weighing over $30 \mathrm{~kg}$ ). The animals were submitted to a caloric restriction weight-loss program until they lose $15 \%$ of the body weight. The M-mode echocardiogram, electrocardiogram, and blood pressure evaluations were performed before the diet has started and after the dogs have reached the target weight. Data showed a decrease in left ventricular free wall thickness during diastole and systole in Group III, decrease in the systolic blood pressure in Group III, and also in the mean blood pressure in Group II. It was possible to conclude that the weight loss program can reverse structural cardiac changes such as left ventricle eccentric hypertrophy in dogs weighing more than $30 \mathrm{~kg}$, and decrease the arterial blood pressure in obese dogs.
\end{abstract}

INDEX TERMS: Echocardiography, electrocardiography, arterial blood pressure, obesity, dogs.

RESUMO.- [Efeitos da perda de peso sobre os parâmetros cardíacos em cães obesos.] A obesidade é uma das doenças nutricionais mais frequentemente observada em cães e pode provocar sérios problemas de saúde, como os distúrbios cardiovasculares. Realizou-se este estudo visando avaliar algumas das possíveis alterações estruturais e funcionais cardíacas decorrentes da correção da obesidade canina. Para isso foram utilizados 18 cães obesos divididos pelo peso corporal em Grupo I (até $15 \mathrm{~kg}$ ), Grupo II (entre 15,1 e $30 \mathrm{~kg}$ ) e Grupo III (acima de $30 \mathrm{~kg}$ ). Os animais foram submetidos à restrição calórica de forma a perderem $15 \%$ do peso vivo. Foram realiza-

\footnotetext{
${ }^{1}$ Received on September 8, 2009.

Accepted for publication on January 7, 2010.

2 Postgraduate student, Departamento de Clínica e Cirurgia Veterinária, Faculdade de Ciências Agrárias e Veterinárias (FCAV), Universidade Estadual Paulista (Unesp), Via de acesso Prof. Paulo Donato Castellane s/n, Jaboticabal, SP 14884-900, Brazil. *Autor para correspondência: glaucia.vet@gmail.com

${ }^{3}$ Departamento de Clínica e Cirurgia Veterinária, FCAV, Unesp, Jaboticabal, SP.
}

dos os exames ecocardiográfico em modo-M, eletrocardiográfico e mensuração da pressão arterial dos animais antes do início do tratamento da obesidade e após atingirem o peso meta. Os resultados revelaram que após a redução de peso ocorreram diminuições significativas da espessura da parede livre do ventrículo esquerdo durante a sístole e diástole no Grupo III, diminuição da pressão arterial sistólica no Grupo III e também da pressão arterial média no Grupo II. Assim, concluiu-se que a perda de peso pode reverter as alterações estruturais cardíacas, como a hipertrofia excêntrica do ventrículo esquerdo em cães obesos acima de $30 \mathrm{~kg}$, como também reduzir a pressão arterial sistêmica em cães obesos submetidos à restrição calórica mediante administração de dieta hipocalórica.

TERMOS DE INDEXAÇÃO: Ecocardiografia, eletrocardiografia, pressão arterial, obesidade, cães.

\section{INTRODUCTION}

Obesity is an important condition that has been a point of concern worldwide and it is considered the main public 
health problem in modern society. In recent years, a great number of obesity in companion animals has been observed. Epidemiological surveys performed in clinics and veterinary hospitals estimate the prevalence of canine obesity between $25-35 \%$ (Greco 2002). Therefore, it is believed that sedentary lifestyles, which have become the norm rather than exception for many dogs, as well the supply of flavourful, hypercaloric foods, contribute to energy imbalances that lead to excess weight (Burkholder \& Toll 2000, Markwell \& Edney 2000).

The obese dog is in great risk of developing chronic health problems including respiratory, cardiovascular, and osteoarticular disturbances. It can also develop hyperinsulinemia, glucose intolerance, exercise and heat intolerance and reduced physical disposition (Case et al. 1998, Markwell \& Edney 2000, Lund et al. 2006, German 2006).

Due to a lack of information on this issue in animals, cardiovascular problems related to obesity in humans are frequently extrapolated to dogs (Atkins 1999). Obesity is a volume expansion illness with high cardiac output, increased plasma and extracellular fluid, neuro-humoral activation, reduced urinary excretion of sodium and water, increased heart rate, elevated arterial pressure, systolic and diastolic ventricular dysfunction, and exercise intolerance (Atkins 1999, Alpert 2001a). Reduction in body weight is capable of reversing the structural and hemodynamic abnormalities associated with human obesity, decreasing left ventricular mass and improving diastolic ventricular filling in patients who have ventricular hypertrophy prior to weight loss. Furthermore, in patients with obesity-associated congestive cardiac failure, reduction of body weight may revert some of the clinical manifestations decurrent of cardiac changes (Alpert 2001b, Uwaifo et al. 2003).

Studies performed in dogs have demonstrated that weight gain in animals submitted to a hypercaloric diet was associated with an increase in heart rate, cardiac output, arterial pressure, plasma volume and fasting insulin; the rise of these parameters is related directly to body weight gain. At the end of the weight loss program it was observed that the analyzed variables gradually returned to their basal values (Rocchini et al. 1987).

The purpose of the study reported herein was to investigate possible structural and functional cardiac changes in dogs submitted to obesity correction.

\section{MATERIALS AND METHODS}

Animals. Eighteen privately owned obese dogs were divided into three groups based on animal body weight. Group I (GI): obese dogs with body weight up to $15 \mathrm{~kg}(\mathrm{n}=6)$. This group was composed of 6 females (5-10 years old), including one Beagle, one Dachshund, one Fox Terrier and three mongrels. Group II (GII): obese dogs with body weight between $15-30 \mathrm{~kg}(\mathrm{n}=6)$. This group comprised 5 females and 1 male (3-11 years old), including one American Pit Bull, one English Cocker Spaniel, and four mongrels. Group III (GIII): obese dogs with body weight above $30 \mathrm{~kg}(\mathrm{n}=6)$. This group comprised 3 males and 3 females (5-11 years old), including one German Shepherd dog, one
Brazilian Mastiff, and four mongrels. All animals were submitted to four exams: physical, hematological (including hemogram and serum dosages of alanine aminotransferase, alkaline phosphatase, creatinine, urea, total protein, albumin, cholesterol, triglycerides, and fasting glucose), electrocardiograph, and echocardiograph. Obese individuals with results within normal parameters in physical and haematological tests and without congenital or acquired cardiac disease participated in the experiment. Consequently, only obese animals ingesting excessive high caloric food were accepted. Obesity was diagnosed based on body inspection and direct palpation. Dogs were classified according to their body condition score (BCS) using a 9-point system, in which animals that presented scores of 8 and above were considered obese (Laflamme et al. 1997). The study protocol was reviewed and approved by an animal care committee of Sao Paulo State University (process number 016914).

Weight loss protocol. All dogs were submitted to a weight reduction program in which they were fed $60 \%$ of their maintenance energy requirements (NRC 2006), calculated by their estimated target weight (TW). TW was considered as actual weight (AW) less 15\% (TW = AW - 15\% AW). A specific commercial hypocaloric $\operatorname{diet}^{4}$ was administered until TW was attained. Caloric restriction (CR) was calculated as $80 \times$ TW $(\mathrm{kg})^{0.75} \mathrm{Kcal}$ of metabolizable energy per day. Weight reduction protocol also included dividing the volume of daily food into at least three meals.

Echocardiography. A complete routine transthoracic echocardiographic examination was performed in each dog with an echocardiograph ${ }^{5}$ and a 5.0-7.5 $\mathrm{MHz}$ mechanical sector transducer. Echocardiographic images were recorded on videotape with a simultaneous lead II electrocardiogram for offline measurements by using the measurement software in the echocardiographic recorder. Hair was clipped between the right $3^{\text {rd }}$ and $6^{\text {th }}$ intercostal spaces, and left $2^{\text {nd }}$ and $7^{\text {th }}$ intercostal spaces. Generous coupling gel was applied to these areas of the thorax immediately before echocardiography was started. Measurements were taken by using two-dimensional-guided Mmode on the standard right parasternal long-axis view at aortic valve level for measurement of left atrial (LA) and aortic diameter (AO); at chordae tendineae level for measurement of left ventricular end-systolic (LVESD) and end-diastolic (LVEDD) dimensions, interventricular septal thickness in systole (IVSS) and diastole (IVSD), left ventricular free wall thickness in systole (LVWS) and diastole (LVWD). Such values were used for calculation of the left atrium-to-aorta ratio (LA/AO), ejection fraction (\%EF), and fractional shortening (\%FS); and at mitral valve level for measurement of E-point to septal separation (EPSS). Heart rate was also calculated based on RR interval determined from simultaneous lead II electrocardiogram (Kittleson \& Kienle 1998).

Electrocardiography. A 6-lead computerized electrocardiogram ${ }^{6}$ was used for the electrocardiography recording. Dogs were positioned in right lateral recumbency and the electrode clips were attached to the animal's skin in the standard positions as described by Tilley (1995). The paper speed was $50 \mathrm{~mm} / \mathrm{sec}$ and the electrocardiogram was standardized at $1 \mathrm{mV}$ $=1 \mathrm{~cm}$. The electrocardiogram analysis was obtained from lead

\footnotetext{
${ }^{4}$ Obesity Canine, Royal Canin.

${ }^{5}$ Pandion S300, PieMedical, Maastricht, The Netherlands.

${ }^{6}$ ECG-PC, TEB, São Paulo, Brazil.
} 
II. We measured the following parameters: duration of $P$ wave (Pms), P wave amplitude (PmV), duration of PR interval (PRms), duration of QRS complex (QRSms), R wave amplitude (RmV), duration of QT interval (QTms), ST segment amplitude (ST), T wave amplitude $(T)$, mean electrical axis, heart rate $(H R)$ and heart rhythm.

Non-invasive arterial pressure evaluation. Non-invasive arterial pressure measurements were obtained from all dogs. Dogs were gently restrained in a lateral recumbency for examination. An oscillometric monitor ${ }^{7}$ was used to obtain measurements with appropriate sized cuff (inflatable bladder width 0.4 times the circumference of limb at measurement site) (Brown et al. 2007). Five consecutive readings were obtained from systolic (SAP), mean (MAP) and diastolic (DAP) arterial blood pressure, the lowest and highest values were discarded and the remaining three averaged.

Statistical analysis. Echocardiographic and electrocardiographic evaluations and measurements of systolic, mean and diastolic arterial pressure and body weight were done before initiating therapeutic weight reduction protocol $\left(T_{\text {before }}\right)$, and after the dog had attained its target weight $\left(\mathrm{T}_{\text {after }}\right)$. Variables analysed at $T_{\text {before }}$ and $T_{\text {after }}$ were compared, observing for alterations resulting from weight reduction. The data was then evaluated using an analysis of variance (ANOVA). The means of dependant variables studied at the two experimental times ( $T_{\text {before }}$ and $T_{\text {after }}$ ) were compared for dogs within the same group. Data are given as mean \pm SD.

Tukey's Studentized Range test was applied to compare the means of Groups I, II and III, with the level of significance at 5\%. For all analysis, it was used a statistical software (Schlotzhauer \& Little 1997).

\section{RESULTS}

All dogs demonstrated consistent weight loss and reached the target weight stipulated by the therapeutic protocol (a minimum $15 \%$ reduction from initial body weight). Analysis of the three groups separately revealed that Group I presented $19.4 \%$ mean weight loss, Group II, $19.3 \%$, and

${ }^{7}$ DX 2710 - DIXTAL non-invasive pressure.
Group III, 15.4\%; similar weight loss percentage between groups (Table 1). With restricting calorie intake to $60 \%$ of maintenance energy requirements, it has observed weekly weight loss percentage of $1.64 \%, 1.07 \%$ and $0.69 \%$ for Groups I, II and III, respectively.

In regards to the echocardiographic data collected in the present research (Table 2), after weight loss a significant reduction was observed in systolic and diastolic left ventricular free wall thickness only in Group III $(p<0.05)$. Percentage reductions in LVWS and LVWD for Group III were $19.08 \%$ versus $13.6 \%$, respectively.

Heart rate, left ventricle diameters, aorta and left atrium diameters and their interaction, mitral valve E-point to septal separation, interventricular septal thickness, ejection, and shortening fractions did not show significant variations in any of the groups after weight loss ( $p>0.05)$. However, some of these parameters that depend on weight (AO, LA, LVED, IVS and LVW) show significant differences among Groups I, II, and III ( $p<0.05)$.

During the evaluation of electrocardiograms it was not observed significant alterations of all electrocardiographic variables studied (Table 3). However, $\mathrm{P}$ wave duration in all dogs from Group III, 20\% from Group I and 40\% from Group II was above normal values for the canine species and body weight. After reaching their target weight, $P$ wave durations for these animals returned to reference values.

A significant decrease in arterial pressure was seen in all dogs after weight reduction (Table 4). It was verified that

Table 1. Percentage of weight loss of dogs from Groups I, II and III (each group, $\mathrm{n}=6$ ), during weight loss program

\begin{tabular}{ccccccccc}
\hline Grupo & 0 & 30 & 60 & 90 & 120 & 150 & 180 & 210 \\
\hline GI & 0 & $6.87 \%$ & $13.98 \%$ & $16.34 \%$ & $19.47 \%$ & - & - & - \\
GII & 0 & $6.43 \%$ & $9.57 \%$ & $12.88 \%$ & $17.95 \%$ & $19.35 \%$ & - & - \\
GIII & 0 & $4.70 \%$ & $6.45 \%$ & $9.67 \%$ & $12.05 \%$ & $13.72 \%$ & $15.09 \%$ & $15.46 \%$
\end{tabular}

$0=$ percentage of initial weight loss; $30,60,90,120,150,180$ e $210=$ percentages of weight loss after $30,60,90,120,150,180$ and 210 days on hypocaloric diet, respectively.

Table 2. Mean values and standard deviation of M-mode echocardiographic parameters obtained from obese dogs of Groups I, II and III (each group, $n=6$ ), before and after weight loss

\begin{tabular}{|c|c|c|c|c|c|c|}
\hline & \multicolumn{2}{|c|}{ Group I } & \multicolumn{2}{|c|}{ Group II } & \multicolumn{2}{|c|}{ Group III } \\
\hline & Before & After & Before & After & Before & After \\
\hline LVESD & $1.76 \pm 0.22^{\mathrm{Aa}}$ & $1.63 \pm 0.37^{\mathrm{Aa}}$ & $2.37 \pm 0.36^{\mathrm{Ba}}$ & $2.37 \pm 0.23^{\mathrm{Ba}}$ & $2.65 \pm 0.38 \mathrm{Ca}$ & $2.92 \pm 0.37 \mathrm{Ca}$ \\
\hline LVEDD & $2.77 \pm 0.50^{\mathrm{Aa}}$ & $2.71 \pm 0.47^{\mathrm{Aa}}$ & $3.66 \pm 0.62^{\mathrm{Ba}}$ & $3.59 \pm 0.32^{\mathrm{Ba}}$ & $4.24 \pm 0.57^{\mathrm{Ca}}$ & $4.38 \pm 0.55^{\mathrm{Ca}}$ \\
\hline IVSS & $0.96 \pm 0.24^{\mathrm{Aa}}$ & $1.06 \pm 0.12^{\mathrm{Aa}}$ & $1.14 \pm 0.17^{\mathrm{Aa}}$ & $1.27 \pm 0.17^{\mathrm{Aa}}$ & $1.54 \pm 0.27^{\mathrm{Ba}}$ & $1.52 \pm 0.14^{\mathrm{Ba}}$ \\
\hline IVSD & $0.72 \pm 0.06^{\mathrm{Aa}}$ & $0.75 \pm 0.12^{\mathrm{Aa}}$ & $0.86 \pm 0.27^{\mathrm{Aa}}$ & $0.89 \pm 0.17^{\mathrm{Aa}}$ & $1.08 \pm 0.26^{\mathrm{Ba}}$ & $1.06 \pm 0.11^{\mathrm{Ba}}$ \\
\hline LVWS & $1.07 \pm 0.14^{\mathrm{Aa}}$ & $0.96 \pm 0.09 A a$ & $1.38 \pm 0.26^{\mathrm{Ba}}$ & $1.23 \pm 0.32^{\mathrm{Ba}}$ & $1.52 \pm 0.41^{\mathrm{Ba}}$ & $1.23 \pm 0.30^{\mathrm{Bb}}$ \\
\hline LVWD & $0.80 \pm 0.07^{\mathrm{Aa}}$ & $0.73 \pm 0.05^{\mathrm{Aa}}$ & $0.93 \pm 0.10^{\mathrm{Ba}}$ & $0.83 \pm 0.13^{\mathrm{Ba}}$ & $1.07 \pm 0.17^{\mathrm{Ba}}$ & $0.84 \pm 0.24^{\mathrm{Bb}}$ \\
\hline$\% \mathrm{EF}$ & $66.80 \pm 7.36 \mathrm{Aa}$ & $72.20 \pm 9.52 \mathrm{Aa}$ & $65.40 \pm 2.97 \mathrm{Aa}$ & $63.20 \pm 7.76 \mathrm{Aa}$ & $67.80 \pm 4.82 \mathrm{Aa}$ & $62.00 \pm 5.29 \mathrm{Aa}$ \\
\hline$\% F S$ & $36.00 \pm 5.96 \mathrm{Aa}$ & $40.20 \pm 7.76 \mathrm{Aa}$ & $34.80 \pm 2.59 \mathrm{Aa}$ & $33.60 \pm 5.86 \mathrm{Aa}$ & $37.60 \pm 3.65 \mathrm{Aa}$ & $33.20 \pm 4.14 \mathrm{Aa}$ \\
\hline $\mathrm{AO}$ & $1.60 \pm 0.21^{\mathrm{Aa}}$ & $1.57 \pm 0.15^{\mathrm{Aa}}$ & $2.06 \pm 0.30^{\mathrm{Ba}}$ & $1.96 \pm 0.17^{\mathrm{Ba}}$ & $2.56 \pm 0.50^{\mathrm{Ca}}$ & $2.58 \pm 0.41 \mathrm{Ca}$ \\
\hline LA & $1.75 \pm 0.16^{\mathrm{Aa}}$ & $1.82 \pm 0.24^{\mathrm{Aa}}$ & $2.17 \pm 0.30^{\mathrm{Ba}}$ & $2.04 \pm 0.09^{\mathrm{Ba}}$ & $2.64 \pm 0.42^{\mathrm{Ca}}$ & $2.75 \pm 0.29 \mathrm{Ca}$ \\
\hline $\mathrm{LA} / \mathrm{AO}$ & $1.10 \pm 0.12^{\mathrm{Aa}}$ & $1.16 \pm 0.11^{\mathrm{Ab}}$ & $1.06 \pm 0.06^{\mathrm{Ba}}$ & $1.04 \pm 0.04^{\mathrm{Ba}}$ & $1.04 \pm 0.08^{\mathrm{Ba}}$ & $1.07 \pm 0.08^{\mathrm{Ba}}$ \\
\hline SSPE & $0.34 \pm 0.15^{A}$ & $0.26 \pm 0.16^{\mathrm{Aa}}$ & $0.31 \pm 0.09^{A a}$ & $0.28 \pm 0.09^{A a}$ & $0.37 \pm 0.13^{\mathrm{Aa}}$ & $0.28 \pm 0.19^{A a}$ \\
\hline
\end{tabular}

$A, B, C=$ means in the same line with different capital letters indicate statistical significance $(p<0.05)$ among Groups I, II and III.

$a, b=$ means in the same line with different small letters indicate statistical significance $(p<0.05)$ between before and after times. 
Table 3. Mean values and standard deviation of the systolic (SAP), mean (MAP) and diastolic (DAP) arterial blood pressure in $\mathrm{mmHg}$ from obese dogs Groups I, II and III (each group, $n=6$ ), before and after weight loss

\begin{tabular}{|c|c|c|c|c|c|c|}
\hline & \multicolumn{2}{|c|}{ Group I } & \multicolumn{2}{|c|}{ Group II } & \multicolumn{2}{|c|}{ Group III } \\
\hline & Before & After & Before & After & Before & After \\
\hline SAP & $134 \pm 6^{\mathrm{Aa}}$ & $118 \pm 25^{\mathrm{Aa}}$ & $143 \pm 6^{\mathrm{ABa}}$ & $137 \pm 7^{\mathrm{ABa}}$ & $158 \pm 20^{\mathrm{Ba}}$ & $144 \pm 11^{\mathrm{Bb}}$ \\
\hline MAP & $97 \pm 4 \mathrm{Aa}$ & $86 \pm 23 \mathrm{Aa}$ & $112 \pm 6 \mathrm{ABa}$ & $92 \pm 13 \mathrm{ABb}$ & $112 \pm 19^{\mathrm{Ba}}$ & $102 \pm 9 \mathrm{Ba}$ \\
\hline DAP & $82 \pm 13 \mathrm{Aa}$ & $68 \pm 24 \mathrm{Aa}$ & $90 \pm 8 \mathrm{Aa}$ & $73 \pm 17 \mathrm{Aa}$ & $90 \pm 18 \mathrm{Aa}$ & $77 \pm 6 \mathrm{Aa}$ \\
\hline
\end{tabular}

$A, B, C=$ means in the same line with different capital letters indicate statistical significance $(p<0.05)$ among Groups I, II and III.

$a, b=$ means in the same line with different small letters indicate statistical significance $(p<0.05)$ between before and after times.

Table 4. Mean values and standard deviation of electrocardiographic parameters obtained from obese dogs of Groups I, II and III (each group, $n=6$ ), before and after weight loss

\begin{tabular}{|c|c|c|c|c|c|c|}
\hline & \multicolumn{2}{|c|}{ Group I } & \multicolumn{2}{|c|}{ Group II } & \multicolumn{2}{|c|}{ Group III } \\
\hline & Before & After & Before & After & Before & After \\
\hline Pms & $45.40 \pm 3.91 \mathrm{Aa}$ & $42.20 \pm 2.17 \mathrm{Aa}$ & $.09 \mathrm{Aa}$ & $42.40 \pm 1.34 \mathrm{Aa}$ & $50.80 \pm 4.27 \mathrm{Aa}$ & $47.40 \pm 2.88 \mathrm{Aa}$ \\
\hline PmV & $0.27 \pm 0.06 \mathrm{Aa}$ & $0.21 \pm 0.06^{\mathrm{Aa}}$ & $12 \mathrm{Aa}$ & $0.26 \pm 0.08 \mathrm{Aa}$ & $0.7 \pm 0.06 \mathrm{Aa}$ & $05 \mathrm{Aa}$ \\
\hline QRSms & $46.80 \pm 6.02 \mathrm{Aa}$ & $49.40 \pm 1$ & $56.80 \pm 7.19 \mathrm{Aa}$ & $57.40 \pm 6.58 \mathrm{Aa}$ & $56.20 \pm 3.70 \mathrm{Aa}$ & $57.20 \pm 4.38 \mathrm{Aa}$ \\
\hline $\mathrm{RmV}$ & $1.04 \pm 0.24 \mathrm{Aa}$ & $1.23 \pm 0$ & $1.82 \pm 0.68 \mathrm{Ba}$ & $1.81 \pm 0.70 \mathrm{Ba}$ & $0.91 \pm 0.44 \mathrm{Ca}$ & $0.95 \pm 0.47 \mathrm{Ca}$ \\
\hline PRms & $94.20 \pm 10.71 \mathrm{Aa}$ & $90.20 \pm 8.44 \mathrm{Aa}$ & $101.40 \pm 3.78 \mathrm{Aa}$ & $116.40 \pm 20.29 \mathrm{Aa}$ & $98.60 \pm 10.69 \mathrm{Aa}$ & $104.80 \pm 8.67 \mathrm{Aa}$ \\
\hline QTms & $183.4 \pm 10.60 \mathrm{Aa}$ & $198.00 \pm 12.61^{\mathrm{Aa}}$ & $205.0 \pm 10.71 \mathrm{Aa}$ & $203.40 \pm 13.67^{\mathrm{Aa}}$ & $210.60 \pm 11.89 \mathrm{Aa}$ & $201.40 \pm 16.86^{\mathrm{Aa}}$ \\
\hline FCbpm & $124.00 \pm 21.85^{\mathrm{Aa}}$ & $102.80 \pm 19.03^{\mathrm{Aa}}$ & $99.00 \pm 12.98 \mathrm{Aa}$ & $105.60 \pm 20.33^{A a}$ & $105.80 \pm 17.48^{\mathrm{Aa}}$ & $115.40 \pm 14.67^{\mathrm{Aa}}$ \\
\hline Eixo & $55.80 \pm 5.89 \mathrm{Aa}$ & $64.40 \pm 15.95 \mathrm{Aa}$ & $60.80 \pm 13.25 \mathrm{Aa}$ & $77.80 \pm 14.75$ Аа & $56.00 \pm 8.66 \mathrm{Aa}$ & $69.00 \pm 22.75 \mathrm{Aa}$ \\
\hline
\end{tabular}

$A, B, C=$ means in the same line with different capital letters indicate statistical significance $(p<0.05)$ among Groups I, II and III.

$a, b=$ means in the same line with different small letters indicate statistical significance $(p<0.05)$ between before and after times.

the decrease was significant for SAP in Group III ( $p=0.0479$ ) and for MAP in Group II $(p=0.0499)$. Arterial pressure decrease for Groups I, II and III were, respectively, $11.94 \%$, $4.20 \%$ and $8.86 \%$ for SAP; $11.34 \%, 17.86 \%$ and $8.93 \%$ for MAP, and $17.07 \%, 18.89 \%$ and $14.44 \%$ for DAP.

\section{DISCUSSION}

The caloric restriction adopted by this research was $60 \%$ of the maintenance energy requirement of each animal. As a result, each group satisfactorily attained the stipulated target weight, with mean weekly loss in agreement with others authors (Laflamme et al. 1997). Mean weight loss rate is directly related to the degree of caloric restriction. In dogs, restricting calorie intake to 50,60 or $75 \%$ of maintenance energy requirements can generate weekly weight loss ranging from less to $1 \%$ to greater than $4 \%$. This considerable variation can be explained by individual animal differences (Laflamme et al. 1997). On the other hand, lower percentage weight losses result in better chances of maintaining post-diet weight (Laflamme \& Kuhlman 2002). According to what was observed in this research, a minimum weekly weight reduction must be $0.5 \%$ in order to keep the animal's owner interested and disposed to complete the weight reduction program within a reasonable period (Burkholder \& Bauer 1998, Burkholder \& Toll 2000).

Basal values for LVWS and LVWD were found to be higher in all groups than values cited as normal by the literature (Kittleson \& Kienle 1998) with normal or no significant mild increase LVESD and LVEDD. Nevertheless, it was not evaluated left ventricle volumes in this research, this characteristic may reflect similarly, to what occurs in obese, normotensive humans - eccentric hypertrophy of the left ventricle resulting from an increase in preload associated with obesity. This eccentric hypertrophy is a mechanism to normalize stress on the left ventricular wall (Alpert 2001a, Vasan 2003). Similar data was not encountered in the findings of other studies when inducing obesity in dogs by administering hypercaloric diets, did not observe any alterations in left ventricle wall thickness (Verwaerd et al. 1996, Massabuau et al. 1997).

The significant mean regression of left ventricular hypertrophy verified in group III after reaching target weight corroborated the findings documented by other researches that demonstrated the effect of weight loss on LVWS and LVWD reduction in humans submitted to hypocaloric diets (Sidó et al. 2000, Uwaifo et al. 2003).

The computerized electrocardiographic evaluation initially showed an increase in mean $\mathrm{P}$ wave duration for $100 \%, 40 \%$ and $20 \%$ of the dogs in groups I, II and III, respectively, compared with normal values for computerized electrocardiography in literature (Wolf et al. 2000), this data could indicate alteration in an electrical conduction thought the atria in obese dogs, but further studies are necessary to prove this hypothesis. After weight reduction, a decrease in duration was observed in all groups, differing from that reported in morbid obese humans (Alpert et al. 2001c). 
Arterial pressure values for all groups at both evaluation times were found to be within the reference ranges for canine species, they were not hypertension, like observed by Rocchini et al. (2004) that conclude hypertension was not directly related to obesity in dogs. As in this work, Brown et al. (2007) observed that overweight dogs possessed higher reference range arterial pressures in relation to those of ideal body weight. As such, food restriction is considered an important non-pharmacological treatment for controlling arterial pressure, especially in dogs of excessive weight (Rocchini et al. 1987, Rocchini et al. 1989).

This study demonstrated that, in consideration of the weight loss protocol employed, dogs presented adequate rates of body weight reduction. It also verified that weight reduction reverts some of the cardiac structural alterations observed through echocardiography, like eccentric hypertrophy in obese dogs above 30 kilograms. Systolic, mean and diastolic arterial pressure dropped significantly in all obese dogs after a $15 \%$ minimum loss of their initial body weight.

Acknowledgments.- To Waltham Foundation (Project 2004/083) for funding and to Royal Canin of Brazil for supporting this research.

\section{REFERENCES}

Alpert M.A. 2001a. Obesity cardiomyopathy: Pathophysiology and evolution of the clinical syndrome. Am. J. Med. Sci. 321:225-236.

Alpert M.A. 2001b. Management of obesity cardiomyopathy. Am. J. Med. Sci. 321:237-241.

Alpert M.A., Terry B.E., Hamm C.R., Fan T.M., Cohen M.V., Massey C.V. \& Painter J.A. 2001C. Effect of weight loss on the ECG of normotensive morbidly obese patients. Chest 119(2):507-510.

Atkins C.E. 1999. Cardiac manifestations of systemic and metabolic disease, p.757-780. In: Fox P.R., Sisson D. \& Moise N.S. (Eds), Textbook of Canine and Feline Cardiology: Principles and clinical practice. $2^{\text {nd }}$ ed. W.B. Saunders, Philadelphia.

Brown S., Atkins C., Bagley R., Carr A., Cowgill L., Davidson M., Egner B., Elliot J., Henik R., Labato M., Littman M., Polzin D., Ross L., Snyder P. \& Stepien R. 2007. Guidelines for the identification, evaluation, and management of systemic hypertesion in dogs and cats. ACVIM Consensus Statement. J. Vet. Int. Med. 21:542-558.

Burkholder W.J. \& Bauer J.E. 1998. Foods and techniques for managing obesity in companion animal. J. Am. Vet. Med. Assoc. 212:658662.

Burkholder W.J. \& Toll P.W. 2000. Obesity, p.401-425. In: Hand M.S., Thatcher C.D., Remillard R.L., Roudebush P. \& Lewis L.D. (Eds), Small Animal Clinical Nutrition. $4^{\text {th }}$ ed. Mark Morris Institute, Topeka.

Case L.P., Carey D.P. \& Hirakawa D.P. 1998. Desenvolvimento e trata- mento da obesidade, p.247-277. In: Ibid. (Eds), Nutrição Canina e Felina: Manual para profissionais. Harcourt Brace, Madrid.

German A. 2006. Clinical risks associated with obesity in companion animals. Waltham Focus 16:21-26.

Greco D.S. 2002. Life is shorter, if you eat desert first: Clinical implications of the purina 448 study. Proc. Purina Pet Institute Symposium, St Louis, p.30-32.

Kittleson M.D. \& Kienle R.D. 1998. Echocardiography, p.95-117. In: Ibid. (Eds), Small Animal Cardiovascular Medicine. Mosby, St Louis.

Laflamme D.P. \& Kuhlman G. 2002. The effect of weight loss regime on subsequent weight maintenance in dogs. Nutr. Res. 132:1799S-1800S.

Laflamme D.P., Kuhlman G. \& Lawler D.F. 1997. Evaluation of weight loss protocols for dogs. J. Am. Anim. Hosp. Assoc. 33:253-259.

Lund E.M., Armstrong P.S., Kirk C.A. \& Klausner J.F. 2006. Prevalence and risk factors for obesity in adults dogs from privates US veterinary practices. Int. J. Appl. Res. Vet. Med. 2:177-186.

Markwell P.J. \& Edney A.T.B. 2000. The obese animal, p.108-115. In: Wills J.M. \& Kelly N. (Eds), Manual of Companion Animal Nutrition and Feeding. BSAVA, London.

Massabuau P., Verwaerd P., Galinier M., Rougé P., Galitzky J., Senard J.M., Berlan M., Bounhoure J.P. \& Montastruc J.L. 1997. Left ventricular repercussion of obesity-induced arterial hypertension in the dog. Arch. Mal. Coeur Vaiss. 90(8):1033-1035.

National Research Council (NCR) 2006. Nutrient Requirements of Dogs. Washington, DC, p.3-38.

Rocchini A.P., Moorehead C., Wentz E. \& Deremer S. 1987. Obesityinduced hypertension in the dog. Hypertension 9:64-68.

Rocchini A.P., Moorehead C.P., DeRemer S. \& Bondie D. 1989. Pathogenesis of weight-related changes in blood pressure in dogs. Hypertension 13(6, Pt 2):922-928.

Rocchini A.P., Yang J.Q. \& Gokee A. 2004. Hypertension and insulin resistance are not directly related in obese dogs. Hypertension 43(5):1011-1016.

Sidó Z., Jákó P. \& Pavlik G. 2000. The effect of moderate weight loss on echocardiographic parameters in obese female patients. Acta Physiol. Hung. 87(3):241-251.

Schlotzhauer S. \& Littel R.C. 1997. SAS ${ }^{\circ}$ System for Elementary Statistical Analysis. $2^{\text {nd }}$ ed. SAS Institute, Cary, NC, p.183-279.

Tilley L.P. 1995. Essencials of Canine and Feline Electrocardiography. $3^{\text {rd }}$ ed. Lea and Febiger, Philadelphia, p.21-39.

Uwaifo G.I., Fallon E.M., Calis K.A., Drinkard B., McDuffie J.R. \& Yanovski J.A. 2003. Improvement in hypertrophic cardiomyopathy after significant weight loss: Case report. South Med. J. 96:626-631.

Vasan R.S. 2003. Cardiac function and obesity. Heart 89:1127-1129.

Verwaerd P., Bordet R., Portolan G., Sénard J.M., Galinier M., Rougé P., Massabuau P., Galitzky J., Berlan M., Lafontan M. \& Montastruc J.L. 1996. Experimental hypertension induced by hyperlipidic and hypercaloric diet. Arch. Mal. Coeur Vaiss 89(8):1019-1023.

Wolf R., Camacho A.A. \& Souza R.C.A. 2000. Eletrocardiografia computadorizada em cães. Arq. Bras. Med. Vet. Zootec., Belo Horizonte, 52(6):610-615. 